\section{SOI: $1.1 /$ TAS DOI: $10.15863 /$ TAS International Scientific Journal Theoretical \& Applied Science}

Khudoyberdi Dilmurodovich Khaknazarov a teacher of Tashkent State Pedagogical University named after Nizami, Uzbekistan gulom1403@mail.ru

p-ISSN: 2308-4944 (print) e-ISSN: 2409-0085 (online)

Year: 2017 Issue: 12 Volume: 56

Published: $21.12 .2017 \quad$ http://T-Science.org

Section 13. Geography. History. Oceanology. Meteorology.

\title{
DAILY ACTIVITIES OF THE YOUTH OF UZBEKISTAN: THEIR TRADITIONS AND TRANSFORMATIONAL PROCESSES
}

Abstract: This article is dedicated to the daily lifestyle of the youth. There are also some information about lifestyle of the youth and factors which influence to them. Besides that, the author presents several issues on researching traditions and transformational prosesses belong to the daily lifestyle of the youth, for instance the youth and education, the youth and sport, how to spend free time and etc. In addition significant importance of self governed organizations in the life of the youth in the last recent years are shown in detail.

Key words: the youth, modern youth, lifestyle, daily life, leisure, makhalla, religious customs, traditions, fashion, social friends, transformation.

Language: English

Citation: Khaknazarov KD (2017) DAILY ACTIVITIES OF THE YOUTH OF UZBEKISTAN: THEIR TRADITIONS AND TRANSFORMATIONAL PROCESSES. ISJ Theoretical \& Applied Science, 12 (56): 55-59.

Soi: http://s-o-i.org/1.1/TAS-12-56-11 Doi: crossef https://dx.doi.org/10.15863/TAS.2017.12.56.11

\section{Introduction}

To the issue of youth is paid respective attention in Uzbekistan and it is highly considered as a state policy. The laws, proclamations and decrees being established in the government require getting concentrated on this case. As the President of the Republic of Uzbekistan Shavkat Mirziyoyev states "It is necessary to develop multilateral cooperation on encouraging the youth socially, defend their rights and interests" [4].

Recently attempts being done on the accomplishment of the state policy concerning to the youth has risen to its new shift. Nowadays $32 \%$ of the total populations of the country, in other words, 10 million people are youth under 30 [3, 145]. Socioeconomic, political and judicial guarantees presented to youth are stated in the new edition of "The law of the republic of Uzbekistan about the state policy on the youth" accepted on September 14, 2016 [2, 80]. This document indicates not only the main branches of the policy relating to the youth but also it clearly defines the responsibilities of organs which execute them. Today this law functions as a primary source which deals with daily problems and difficulties of youth.

\section{Materials and Methods}

Furthermore youth are main social demographic layer of the state population and they include themselves a group of people mainly from 16 to 30 . This period is considered as a shift of human life which is characterized with the ending of education and the beginning of career, having a family and being independent both materially and spiritually [7,7].

Together with the increase of the attention to the youth policy there are being investigated scientifically and practically the essential features connected with the life of youth such as their upbringing and educations, lifelong ambitions of the youth, their dreams and objectives, the samples of the attention in the degree of state policy and their results, problems of youth and their avoidance and others. Learning daily activities of the youth is also vital in this matter. The issue of daily activities and daily life has started to be studied as a crucial factor of historical investigations almost recently. Whereas day-to-day activities, work, leisure activities, to participate in different customs and traditions and efficient free time use used to be examined separately before, now it is required to research them together with daily life system. Thus the histories of daily life, culture and other related issues have become a critical 
exploration objective. The information and studies on daily life are not considered crucially important for the history but they serve as an additional material for the science. Moreover daily or real life activities are accounted as a way of attracting a person to the life of a society and it is required by objective circumstances and subjective factors which include themselves the rules of human life activities, their results and meaning $[6,72]$.

The inheritance and the acquisition of the features of daily life activities by the youth, their capability to multiply them and readiness for it, is socially and historically important phenomenon as past is crucial for us as an active, dialectic and initial stimuli which teaches us to avoid and turn a matter to an incredible way [8, 252-261].

Daily culture is mainly focuses on people's daily activities, social status, their thoughts and ambitions. Daily culture includes itself the studies of behavior, daily and casual customs and traditions, their beliefs, communicative culture, outlook and together with them distinctive features of formation as one group, clan, people and nation throughout history. Three main branches: labour or preparation to labour activity (study or working time), householdthe time spend on doing housework, looking after oneself, shopping and other related things (off time), the proportion of definite duties and free of responsibilities is the vital basis of youth life [13, 1 2].

There are the imperative issues which should be taken into deeper consideration in exploring youth life:

\section{Youth and education}

Youth are active social layer of the society who generate in the secondary, secondary-special and higher educational institutions. In Uzbekistan, as it was in all fields, there have been accomplished significant innovations in the field of education lately. As youth spend most of their time in educational institutions, in these socializing circumstances they not only get some knowledge there but also they get spiritual and moral instructions.

As it is stated in the Strategy of actions in 20172021 to develop the Republic of Uzbekistan the following are currently the most vital tasks to put forward: to enforce the role of "mahalla" in educating and upbringing of young generation, to create them new employment options, to help the employment of women, to support new established families, to raise patriotic youth, to increase their social activeness in deepening the democratic reforms and developing the civil society, to promote healthy lifestyle in the life of youth, to attract their attention to sport and physical training, to organize effective cooperation of state authority and other government organizations, educational institutions and youth union and other establishments in fulfilling the state policy on the youth [1,112].

As the education system of the country is progressing youth are being encouraged to be active in all the stages of the education including higher and post-graduate study. To analyze the social activity of youth in education gives the opportunity of identification of self-evaluation of the youth to their own level of education, the most attractive specialties, their attempts to choose the suitable professions and their readiness to the language and information. Uzbekistan supports the young generation to continue their study after compulsory education. In response to this youth also feel confident about the guarantee of higher education to qualified specialty. In the experiment first of all the tendency of rise of aspiration of youth to enlarge their knowledge was studied. In the end Uzbekistan people showed their need to raise their knowledge in the future. (table 1)

Table 1

The distribution of the answers to the question "Do you want to raise your education in the future?" in \%.

\begin{tabular}{|l|c|c|c|c|}
\hline & $\mathbf{2 0 1 4}$ & $\mathbf{2 0 1 5}$ & $\mathbf{2 0 1 6}$ & $\mathbf{2 0 1 7}$ \\
\hline Yes, I want & 56.5 & 57.3 & 57.8 & 62.7 \\
\hline Now, I don't want & 28.9 & 29.6 & 30.8 & 26.6 \\
\hline It is difficult for me to answer & 14.6 & 14.1 & 11.7 & 10.6 \\
\hline
\end{tabular}

In this matter the indications of the desire of higher education among urban youth has risen $(66.9 \%, 54.5 \%$ in 2016$)$ whereas the clue indicated fall in rural area $(59.1 \%$ in $2016 ; 58.8 \%$ in 2017).

To be a higher educated specialist is considered to be daily life and future ambition of youth. The results of the survey held on identifying the social importance of higher education among the youth of the country affirm the tendency of rise. For instance, in the toll 2010 and 2011 only a third of the youth, in 2013 every other young citizen- $57.2 \%$, in $201573 \%$, in $201674.7 \%$ of respondents expressed the desire of having higher education. The questionnaire of 2017 coincide to the results of precious research-76.5\% (56.3\% bachelor's degree, $20.2 \%$ master's degree are desired to acquire) [14].

To the question "What is the attraction of higher education for you?" $69.2 \%$ of Uzbekistan youth 
stated that it gives them opportunity to possess the necessary specialty for life $(69.1 \%$ in $2016,71.9 \%$ in $2015,67.3 \%$ 2014). Every five of the respondents $(19.8 \%)$ assess the social status of the higher education as a motivation to study it $(20 \%$ in 2016 , $22.6 \%$ in $2015,21.5 \%$ in 2014 ). $5.6 \%$ of the youth questioned wants a well-paid job $(8.7 \%$ in 2016, $4.7 \%$ in $2015,8.8 \%$ in 2014$), 1.5 \%$ of them are attracted by the chance of employment $(1.5 \%$ in $2016,0.8 \%$ in $2015,2.4 \%$ in 2014) [14].

\section{Youth and labour}

One of the most important daily activities of youth is considered to be their career and business. In this occasion youth should be directed to the proper labour activity and they also should be supported to deal with the job connected to their own specialty. According to the results of the survey carried by the centre of studying common sense of the society "Ijtimoiy fikr" the number of the youth working on their own specialty is rising( it was estimated $59.8 \%$ in 2013 and $62 \%$ in 2014) [14].

Today a third $(34.2 \%)$ of the youth of Uzbekistan work, another $14 \%$ are studying in Higher education, the rest $34.4 \%$ are the students of schools, lyceum and colleges. According to the toll results the employment degree is directly connected to the level of education. For example, $71.7 \%$ of the questioned youth were employed higher educated people whereas $20.8 \%$ and $40 \%$ of the respondents graduated secondary school or vocational colleges [14].

\section{Youth and daily affairs}

One of the primary objectives of social policy of the country is to support the youth, care about their health, to provide education, to raise their talent and to create opportunities for housing. As it is reported in the research, after the independence of the country there have been large opportunities to be active in social and political life $(28.9 \%)$, to choose a profession $(22.5 \%)$, to learn foreign languages (18.8\%) and to study abroad (7.5\%). The study shows that nowadays the youth are not inattentive to the negative situations in society. The youth are more worried about religious extremism (52.1\%), criminality (47.5\%) and drug addiction (36.7\%) [14].

\section{Youth and mahalla (county)}

Major part of the social life of the youth is connected with mahalla- an important social institution. From the past mahalla is considered to be the centre of up-bringing, customs and traditions and nowadays its power is broadening. In solving the problems about all the aspects of the life of youtheducation, sport, leisure activities, participating in different cycles and other issues mahalla is accounted to be close cooperator of a family as a selfoperating branch of the government. Currently mahallas are fulfilling 30 socio-economic tasks which were previously the prerogative of local authoritative organs of the government [11. 170-171]. In this term mahallas should function in the following ways to support young generation and to raise their role in society:

To promote the idea of up-bringing of an ideal person among parents, educational institutions, family and wider society;

To find the talented youth and to work with their spirituality separately;

To direct the youth to a profession according to their interests;

To organize various clubs and cycles (science, professional, amateur, sport and etc) to have the youth spend their leisure time fruitfully;

To prepare the young generation to future parenthood;

To fulfill the systematic events to rise legal and social activeness of the youth;

To support young families, to incentive active youth in front of mahalla and bigger society and other important functions

All in all mahallas are nowadays doing the 30 or more activities which used to be under control of local authorities previously.

\section{The rules of using leisure time}

One more important daily activity of the youth is spending leisure time. According to the survey 46.1 per cent of the younger generation spend their time reading books, 33.3 per cent doing some sports, 17.2 per cent doing household, 15.3 percent going in for various clubs, $9.6 \%$ go to libraries, $8.6 \%$ going to the cinemas and theatres, $6.9 \%$ reading newspaper and watching television, $5.5 \%$ have a rest with friends, 4 percent prefer to spend their free time going to cafes, disco bars and restaurants [10, 351]. Some of the above given numbers are changing somehow these days. There have been appearing new activities while some of the existing getting out of use slowly. Half of the youth $(50.1 \%)$ stated their satisfaction from their leisure time activities, a third of them (31.7\%) expressed slight satisfaction, every third of them $(10.7 \%)$ claimed absolute dissatisfaction. Visiting libraries also have become inseparable activities of some of young people. For instance, according to the report of the modernized National Library of Uzbekistan named after Alisher Navoiy in the first half of 2017 checked in 170060 users most of whom were youth [15].

\section{Youth and spirituality}

The study of spiritual and moral outlook of the youth is considered as necessary task to realize the 
program of additional activities to accomplish the state policy on youth of Uzbekistan as well as it is an indicator of the system of socio-cultural branch among values of society (table 2).

Table 2

The youth opinion about the qualities identifying a person's spirituality.

\begin{tabular}{|l|c|c|c|c|}
\hline \multicolumn{1}{|c|}{ Variants } & $\mathbf{2 0 1 7}$ & $\mathbf{2 0 1 6}$ & $\mathbf{2 0 1 5}$ & $\mathbf{2 0 1 4}$ \\
\hline Knowing the country's history & 68.2 & 63.2 & 66.5 & 62.3 \\
\hline Respecting the national traditions & 65.1 & 62.3 & 65.5 & 56.3 \\
\hline Honesty and hardworking & 66.0 & 52.4 & 49.6 & 43.5 \\
\hline Forming the feeling of national pride & 49.9 & 46.5 & 47.9 & 40.2 \\
\hline Purity of soul (Innocence) & 41.6 & 34.9 & 31.7 & 28.9 \\
\hline National and religious tolerance & 32.3 & 33.3 & 35.2 & 27.8 \\
\hline Modesty & 37.0 & 30.5 & 26.7 & 27.0 \\
\hline
\end{tabular}

\section{Youth and the internet}

The development of information technologies is one of the important indicators of the modern world. Information technologies creates the bases of information for education and science, eases the spread of knowledge and news to every member of the community, in general meets the economic and social requirements of society.

The target of the social survey was to identify the young respondents' evaluation of their own computer literacy and their use of World Wide Web taking into account the vital role of the computer, the culture of the use of information in their life and the role of the IT for them in their professional development.

According to the survey their own evaluation of their computer literacy is constantly rising $(42.3 \%$ in $2014,45.7 \%$ in $2015,49.8 \%$ in 2019 and $52.5 \%$ in 2017) (table 3 ).

"How is your computer literacy?"

Table 3

\begin{tabular}{|c|c|c|c|c|}
\hline & 2017 & 2016 & 2015 & 2014 \\
\hline I can freely use from computer & 52.5 & 49.8 & 45.4 & 42.3 \\
\hline I can use some of the programs of computer as a user & 32.0 & 30.0 & 26.6 & 25.7 \\
\hline I can use computer for typing some text & 7.5 & 10.4 & 16.4 & 20.3 \\
\hline I cant use computer & 8.0 & 9.8 & 11.6 & 11.7 \\
\hline
\end{tabular}

According to the questionnaire $8.5 \%(12.5 \%$ in 2016) of the youth use the Internet all the time, $20.5 \%$ sometimes (30.7\% in 2016), 33.1\% don't use the Internet $(56.8 \%$ in 2016) [14]. In the regional division the young people of Tashkent city $17.7 \%$, Bukhara $14.5 \%$ and $11.8 \%$ Tashkent regions are the most active users. Th youth of urban area are significantly active in comparison to rural area $(11 \%$ and $6 \%$ ).

The respondents claim that their parents control their time in front of the Internet to some extent. So the participants responded to the time management by their parents as $35.4 \%$ are permanently controlled, $28.8 \%$ from time to time, $34.5 \%$ youth are never disciplined by their parents in the Internet use. $74.3 \%$ of $16-17$-year olds, $68.2 \%$ 14-15-year olds claim that they are always controlled by their parents in terms of their Internet usage (in comparison with $27.9 \%$ of 20 -24-year olds, $13.5 \%$ of 25 -29-year olds). The percentage 63.8 was verified by the replies of the students of school, lyceum and vocational college [14].

\section{Youth and healthy lifestyle}

Healthcare of the population is one of the most essential sectors of the social policy of Uzbekistan. It expresses itself a social custom too.

The following indicators were used to study for the ideology of the youth on healthy lifestyle:

To evaluate self health condition;

The attempts to save or destroy health in lifestyle;

To evaluate the facilities to go in for sports.

The research gave the opportunity to learn that youth behave subjectively in the issue of their own health. In other words, the acquired information was not a real condition of health but personal opinion. The tendencies absolutely healthy $66.4 \%$ and overall healthy $26.2 \%$ were dominant in young Uzbeks. If compare with the survey of 2016 there was a decrease in number of young people considering 


\begin{tabular}{|c|c|c|c|c|c|c|}
\hline Impact Factor: & $\begin{array}{l}\text { ISRA (India) } \\
\text { ISI (Dubai, UAE } \\
\text { GIF (Australia) } \\
\text { JIF }\end{array}$ & $\begin{array}{l}=1.344 \\
=0.829 \\
=0.564 \\
=1.500\end{array}$ & $\begin{array}{l}\text { SIS (USA) } \\
\text { PUHЦ (Russia } \\
\text { ESJI (KZ) } \\
\text { SJIF (Morocco }\end{array}$ & $\begin{array}{l}=0.912 \\
=0.207 \\
=\mathbf{4 . 1 0 2} \\
=\mathbf{2 . 0 3 1}\end{array}$ & $\begin{array}{l}\text { ICV (Poland) } \\
\text { PIF (India) } \\
\text { IBI (India) }\end{array}$ & $\begin{array}{l}=6.630 \\
=1.940 \\
=4.260\end{array}$ \\
\hline
\end{tabular}

themselves absolutely healthy $(74.5 \%$ in $2016,66.4$ $\%$ in 2017).

\section{Conclusion}

Apparently, living conditions of youth: family, mahalla, colleagues, social life, leisure time and others indicate their interests, outlook and, there are more of these kinds of bases of daily life of young generation. There can be more information presented about them. But if the talk is about the main activities of daily life the above mentioned criteria are the most appropriate ones.

All in all modern youth of the country should always study in order to achieve high goals in life by using the facilities created by the government and should work hard to be real owner of their future profession as it is practically identifies the future wellbeing of the state.

\section{References:}

1. (2017) The decree of the president of the Republic of Uzbekistan. Strategies of the activities on further development of Uzbekistan Republic. Tashkent: Publishing house "Adolat" on the Ministry of Justice of the Republic of Uzbekistan. 2017. -p.112.

2. (2016) The law of the Republic of Uzbekistan. On the state policy related to the youth. (the set of laws of the Republic of Uzbekistan, 2016, 37 edition, article-426). - Tashkent: Publishing house "Adolat" on the Ministry of Justice of the Republic of Uzbekistan. 2016. - p.80.

3. Mirziyoyev Sh.M. (2017) "We shall rise our national development way to a new stage by continuing it with perseverance" $1^{\text {st }}$ volume. T.: "Uzbekistan", -p.145.

4. (2017) The speech of the president of the republic of Uzbekistan, Shavkat Mirziyoyev in $72^{\text {nd }}$ session of the UN General Assembly// Khalk Suzi. - 2017. - 20 September.

5. Abdullayev M.A., Norkhulov D.T. (1995) "Spirituality and succession in the time system". - T.: TashSU, 1995, - p. 5-7.

6. Bobomurodov E, Bobomurodova Sh. (2010) "Social psychology of the youth of Uzbekistan". T.: "Uzbekistan", 2010. - p.72.

7. Vishnyak A.I., Tarasenko V.I. (1988) "Culture of youth leisure" Kiev. "High school" 1988, p.7.
8. Tulenov J.T. (2001) "Theory of dialectics". T.: "Uzbekistan", 2001. -p. 252-261.

9. Ubaydullayeva R., Ata-Mirzayev O, Khayumov U, Koranov M. (2014) "Social appearance of the youth of Uzbekistan (Sociological experiment)". Tashkent. "Adabiyot yulduzlari". 2014. - p.81

10. Ubaydullayeva R., Ata-Mirzayev O.B. (2017) "Uzbekistan in the mirror of common sense". T.: "Ikhtisod -Moliya". -p. 351.

11. Kholmatova M. (2000) "The culture of family relationships and upbringing healthy generation"- T.: "Uzbekistan", 2000. - p. 170184.

12. Kayumov U. (2011) "The socializing process of Uzbekistan youth in the condition of formation of civil society". T.: "Ijtimoiy fikr". 2011. - p. 57-58.

13. (2012) "Mahalla is place of democratic values", Khalk suzi, 2012, March 10. N-49. - p.1-2.

14. (2017) Informative Analytic lecture on the results of sociological experiment called "The youth of Uzbekistan: lifelong values, spirituality, social directions" held by the centre of exploration of common sense "Ijtimoiy Fikr" in 2017.

15. (2017) Analytic report on the first half of the year of the National library named after Alisher Navoiy in 2017. Available: http://natlib.uz (Accessed: 10.12.2017) 